\title{
Doing Gender Online: Digital Spaces for Identity Politics
}

\author{
Olga Andreevskikh and Marianna Muravyeva
}

\subsection{INTRODUCTION}

In contemporary Russia, online discourses on gender reflect the complex legacies of the Soviet and post-Soviet attitudes and approaches to masculinity and femininity. These complexities are defined by the seemingly contradictory combination of Russia's cultural matrifocality (i.e. reliance on women to run households in the absence or less significant presence of men in family life) and patriarchal social order (Kon 1995). They have also been affected by the new gender identities which evolved during the temporary liberation of Russian society in the 1990s. The appearance of the concept of "sexual freedom" in the post-Soviet Russia, as well as the critical rethinking of the Soviet gender rolesthe "emasculated" men (Kay 2006) and the desexualized "masculinized" women under the "double burden" (Stella and Nartova 2015, 37) —led to the emergence of new gender contracts. These included the "housewife" and the "sponsored contract" - a type of relationship between wealthy men and women where the former sponsor the latter by paying their bills and offering gifts in return for sexual and romantic encounters (Zdravomyslova and Tyomkina 2007; Pilkington 1996; Stella 2015), as well as the new aesthetics and ideology of "glamur" ("glamor") (Goscilo and Strukov 2011). The emergence of grassroots feminist and LGBTQ (lesbian, gay, bisexual, transgender, queer) rights

O. Andreevskikh

University of Leeds, Leeds, UK

M. Muravyeva $(\bowtie)$

University of Helsinki, Helsinki, Finland

e-mail: marianna.muravyeva@helsinki.fi

(C) The Author(s) 2021

D. Gritsenko et al. (eds.), The Palgrave Handbook of Digital Russia

Studies, https://doi.org/10.1007/978-3-030-42855-6_12 
movements led to the rise of the visibility of new types of masculinity and femininity in public discourses - that is, queer, gay, lesbian and transgender identities. The shift from the command to mixed economy and the overall democratization of the public sphere, in general, also led to the increase in women's involvement in various forms of civic activism, which in Russia tends to be historically associated with maternal care (Salmenniemi 2008).

While Russian women explored new opportunities and fought the challenges of the new capitalist society, Russian men appeared to be even deeper impacted by the radical social shifts and especially by the economic and political turmoil of the 1990s. The dramatic changes in Russian masculinities are rooted in the Soviet gender order which consisted in men being deprived of the patriarchal status in the family by the state patriarch. In the post-Soviet times, the paradox of masculinity (Kaganovsky 2008, 4) was complicated by men losing their positions on the economic and political arenas to women, as well as by the rise of nationalism and militarism in socio-political life (Yusupova 2018; Sremac and Ganzevoort 2015). Russian men faced a new crisis of masculinity, this time being deprived of their professional dignity and achievements (Goscilo and Hashamova 2010; Kay 2006).

The current discourses on gender, despite the post-Soviet socioeconomic changes, continue to maintain the patriarchal matrifocal dichotomy, which in its turn affects the digital construction of gender. The Internet is seen as a predominantly male activity (Huppatz 2012), monopolized by men as part of gendered masculine capital (Bourdieu 2001), that is, a patriarchal digital space. Early internet scholars while explaining the relative absence of women online pointed to how the World Wide Web (WWW) was constituted dominantly as a "white male playground" (Green and Adam 2001). They made evident how men took over discussions online, even when they were directly related to women and their gendered experiences. Other scholars often hailed "cyberspace" as an arena where individuals could escape social shackles of their biological gender. In their vision, digital technologies facilitated bodily transcendence, catalyzed new ways of engaging in gender politics and provided new contexts whereby individuals could reconstruct their identity free from bodily stereotypes (Castells 2010; Plant 2000). Contemporary researchers take this discussion to a different level by looking at the Internet and related digital technologies (such as social networks and online platforms) as material actors that perform important tasks within dynamic settings, that is, a form of digital work that creates, maintains and transforms human institutions alongside new information technologies (IT) uses (Arvidsson and Foka 2015). These approaches are particularly relevant to booming digitalization in Russia, where women and men go online to perform a material-discursive translation of digital technologies and their cultural use to enable and constrain certain activities, roles, and identities (Hodder 2012). In other words, women and men take their materiality with them into cyberspace, which often becomes further oppressive rather than liberating. 
Thus, mirroring the gendered discourses on masculine and feminine roles and patterns of behavior, digital media spaces impose similar restrictions and expectations on female users as those experienced by women in their offline activities. Therefore, female activists operating online tend to be seen as transgressing the accepted gendered behavioral norms solely by the fact of their leadership in digital media. When engaging in any interaction or activity online, women are expected to employ their feminine emotional capital in socially acceptable ways (i.e. providing emotional labor for the benefit of others), and the failure to do so tends to cause disapproval and criticism. At the same time, digital spaces attract female users interested in civic activism, which on the contrary is seen as non-transgressive. This paradox creates a complex environment for individual users and for virtual communities engaged in constructing alternative gendered identities online, both feminine and masculine.

This chapter offers an analysis of how the World Wide Web and digital technologies influence gender identity politics in contemporary Russian society. We look at the ways Russians construct gender online, how their practices become means of resistance and activism, and how they adapt and shape digital technologies to perform their gender identities and communicate with the State in the situation of increasing surveillance and control of material and cyberspaces.

\subsection{Constructing Gender Online}

One of the responses to the post-Soviet crisis of masculinity and the emerging feminist movements that are perceived as a direct personal threat by some Russian men has been a rise in radical anti-feminist and masculinist movements operating primarily in online, digital spaces. Fuelled by the state-sponsored ideology of "traditional values," misogyny became a part of any online debate (see also Lokot 2019). New versions of and new views on masculinity have been shaping up, with the gendered masculine identity being rethought through the opposition to "woman" as the "other" and reimagined in a world where women would not exist at all or would play a less prominent social role. These new views on masculinity can take relatively harmless forms, such as Internet memes. For example, since approximately 2012 there has circulated a popular meme "We don't need chans" ("tân ne nužny"). ${ }^{1}$ It was first applied by fans of Japanese anime, hence the use of the Japanese suffix $ち ゃ ん$, Eng. "chan" / Rus. "tân" (a form of reference to children, female family members and female friends), but soon gained viral popularity on Runet. Oftentimes the new masculine identities are not only openly misogynist but are borderline extremist: one such example is the radical misogynist online community MD (Mǔsskoe dviženie, Masculine Movement; over 34,000 followers in March 2020). ${ }^{2}$ The community's motto is "We are not fighting against women-we are fighting for men's rights." The MD public accepts female members provided they do not post any content or comment, that is, have no voice, and the content circulated by the public consists mostly of misogynist hate speech and discussions of what is perceived by the public community members as violation of men's rights. 
Radical masculine movements existing as offline groups or online communities are by no means a specific feature of Russian society - in this respect, Russia is fully included into the global trends of anti-feminist backlashes. Another example of Russia following the global developments in terms of renegotiating gender roles and gender (in)equality is the popularity of the extremist movement of incels, ${ }^{3}$ or "involuntary celibates," which started in 1997 as an online community where its members shared their life experiences. It soon developed into a radical anti-feminist misogynist movement and is currently being spread across the globe, including Russia. ${ }^{4}$ There, one of the best-known incels is probably Aleksej Podnebesnyj (aka Alex Undersky) - a Nizhny Novgorodbased anarchist and civic rights activist notorious for his misogynist social media posts calling for the end of women's rule, which he refers to as "vaginocapitalism," and for physical violence against women and, especially, feminists. As a result of Podnebesnyj's activity on social media, in December 2019 a court case was started to investigate into the man's extremist rhetoric against women. ${ }^{5}$

The accessibility of various social media platforms has enabled Russian men to explore their gendered identities through the construction of online hopedfor selves (Bouvier 2018) and outside of the agendas of grassroots movements. For these alternative masculinities the visual representations of gendered identities are particularly important, and picture- and video-based platforms-Instagram, TikTok and YouTube-have become a primary digital space for expressing those alternative masculinities (Kudaibergenova 2019). For example, the October 2019 ratings of top-twenty Instagram accounts and TikTok bloggers showed that the number two position in the rating was taken by the blogger Sima (@alexmymymy; over 31.1 million followers in March 2020) with almost three million followers. ${ }^{6}$ Young and bold, Sima experiments with camp visuality, representing a queer take on masculinity, for example, through the use of make-up and feminine clothes. ${ }^{7}$

The popularity of bloggers like Sima is not a one-off success but rather a social media trend, with openly gay queer bloggers like Andrei Petrov attracting thousands of subscribers (in March 2020, Petrov's YouTube channel had 1.05 million subscribers). ${ }^{8}$ Petrov, who identifies as a gay cisgender man and uses his channel primarily to offer advice on beauty products, make-up trends and fashion, positions himself not only as a beauty and lifestyle blogger but also as a spokesman for the LGBTQ communities. Thus, on November 27, 2019, alongside five other openly gay celebrities and public figures, he participated in the YouTube TV show “Ostorožno, Sobčak!” (Beware of Sobchak!) hosted by the oppositional pro-LGBTQ celebrity politician Kseniya Sobchak. The episode was called "Coming-outs, gay-lobby and banning of propaganda: six gays and Sobchak" and was devoted to a range of issues connected with LGBTQ rights in Russia. ${ }^{9}$

The examples of Sima and Andrei Petrov demonstrate that Russian social media have become a relatively safe digital space for constructing transgressive non-heteronormative masculinities as far as adult audiences are involved. The online practices applied by Russian women also include transgressive patterns 
of gendered behavior, which is consistent with the emergence of new gendered identities over the post-Soviet decades and which reflects the ongoing renegotiations of gender inequality and the relationships within the binary dichotomy "men-women." For example, resisting the neo-conservative socio-political turn which took place in Russian public discourses throughout the 2000s and 2010s (Cucciola 2017), women have been challenging the imposed gender stereotypes about women's primary social roles being those of mother and wife. On the Russian social networking site VKontakte, public online communities like "Ŝast'e materinstva" (Ze joy of motherhood; over 75,000 subscribers in March 2020) ${ }^{10}$ and "Ŝast'e byt' ženoj" (Ze joy of being a wife; over 28,000 followers in March 2020 ${ }^{11}$ aim to disclose the truth about the challenges, difficulties and obstacles women face when performing the "traditional" gender roles, including domestic violence, mental health problems, financial struggles and broken relationships. Female inclusivity bloggers on platforms like Instagram, for example, Eleni (@loukoumh; over 65,500 followers in March 2020) or Ekaterina (@ekaterinaxiii; over 23,900 followers in March 2020), share digital images representing body-positive non-stereotypical concepts of female physicality and beauty. ${ }^{12}$ Feminist bloggers like Tatyana Nikonova (@ nikonova.online; over 243,000 subscribers on Instagram in March 2020), who is active across various social media platforms-Telegram, VKontakte, Facebook and Instagram - tackle various aspects of female sexuality and desire, offering open and honest advice on a range of issues, from choosing a sex toy to resolving the problem of sexual incompatibility between partners.

These insta-gender practices represent non-violent resistance or quiet activism women have been employing in the past decade to carve out their online space.

\subsection{Digital Services for (wo)men: Creating Gender-SPECIFIC SPACES}

Challenging gender binaries and traditional gender roles is also achieved by translating socio-economic materiality into digital spaces. With the rapid digitalization of services Russian state has been offering, women move online to perform their femininities and "traditional" roles of motherhood by using digital services to take care of their health, diet, body politics and, even, protect themselves from abuse. Women first organized around internet or web forums that served as an online discussion/message boards specialized around certain themes. Eventually those evolved into full time web resources and communities for women to exchange experiences and get help and information. Forums such as www.myjulia.ru (launched in 2008) or www.woman.ru (based on internet magazine launched in 2016) cater to different groups of women and cover a wide range of topics on health, beauty, personal relations, intimacy, family and sex. More specialized forums include www.baby.ru (launched in 2009) or www.materinstvo.ru (in existence since 1999) that provide health and 
educational advice for expecting and experienced mothers, but also provide a discussion space for women. While these online spaces are tagged by scholars as "traditional" (Gnedash 2012), they can also be viewed as a site of quiet activism (Pottinger 2017) where women manage and practice their femininity the way they see appropriate to them.

Women have also quickly learnt the advantages of digital citizenship, that is, using state-provided digital platforms to improve their wellbeing. One of these digital platforms-omnipotent Gosuslugi (Public services portal)—offers a range of services to make women's lives better. Thus, everyone can make an appointment with health services, that is often important for women with small children, that they could do it from home and not call or go in person. Another service-enrolling children into kindergarten or school-is supposed to remove obstacles for disadvantaged families and make the procedure more transparent. While these services are positioned as gender-neutral - any one of the parents could use them-in reality it is still women who are tasked with everything related to motherhood and family obligations. Therefore, women not only become active digital citizens, they also are the ones who provide a feedback to the state to make these technologies better (see also Vivienne et al. 2016).

The IT industry has recently moved to create gender-specific apps to gain additional markets and better appeal to the user. In this move, gender dynamic remained essentially the same and even has been further re-enforced by pushing women to use more health apps (such as mHealth, dieting, yoga, fitness and other apps) and reproductive apps (such as baby.ru app to monitor pregnancy and breastfeeding or time-factor app to monitor monthly periods, both created by men). This distribution of apps promotes the healthy female subject who is embodied in three types of subject positions: (1) Barbie; (2) Earth goddess, and (3) entrepreneur. These themes fix White, middle-class, skinny, young, and fertile female bodies as the standards for health. Women are encouraged to achieve these bodies through practices of self-surveillance, disclosure, and self-advocacy, which are encouraged and normalized through routine use of apps. Thus, apps allow women to actively participate in choosing traditional subject positions, revealing the postfeminist sensibilities of this form of technology-based embodiment (Doshi 2018). At the same time, maternity apps help women self-survey their reproduction and claim autonomy by avoiding medical professionals for frequent check-ups.

By contrast, male apps reproduce masculinity, healthy male body, sexuality and grooming. In Russia, app market is especially full of barber and other grooming apps (such as Muzhikipro app) that claim to turn men into "real men." Other apps such as Yourbro app are reinforcing heterosexual male identity by exploiting porn and female body. Sex is central for new digital technologies. Dating apps occupy a significant segment of Runet: alongside international Tinder and Grindr apps, Russia developed their own dating services such as Rambler dating app or the newly produced by VKontakte's owners the Lovina app. Scholars suggest that while hetero-apps have a power to reinforce gender 
stereotypes and heteronormativity, they empower and compromise women at the same time (Solovyeva and Logunova 2018; Chan 2018). Women receive opportunities to challenge traditional feminine behavior as chaste by arranging multiple and anonymous dating as well as sharing their experiences about dating apps (as above-mentioned blogger Tatyana Nikonova does). At the same time, they put themselves in a position of criticism and vulnerability.

Women's safety has become a part of Russian public discourse, thanks to massive online campaigns and activism, which we will look in detail in the following sections. The app market responded by creating safe apps (such as Between Us from Vodafone) for women that allow to share locations, make fake calls, and push the emergency button. The feminist non-governmental organization (NGO) Nasiliu.net (Stop violence), that has a very prominent presence online and provides services to survivors of gender-based violence, created their own app (bit.ly/NasiliuNetIOS for IOS and bit.ly/ NasiliuNetAndroid for Android), which has the complete information regarding shelters, crisis centers, legal aid and other useful information for women, but mostly importantly has an SOS button that allows to alert people who the user trusts about danger at home and on the street. The developers hope that the app radically contributes to women's wellbeing. ${ }^{13}$

Assessing women's presence online, cyberfeminist theoretical framework offers to look at it as an "alliance" or "connection" between women and technology by exploring the intersection between gender identity, culture and technology (Mohanty and Samantaray 2017). Digital space liberates women and challenges binary gender order by its very process of transgressing material reality into digital one. Women increasingly use online and social networking for activism and mobilization in ways that were not possible before. One of those ways is to make women visible via feminitivy (feminitives)-feminine gender counterparts of all lexical terms denoting professional occupations used by Russian feminists to fight against the invisibility of professional women in public discourses (Guzaerova et al. 2018). In linguistics, the category of gender includes grammatical, lexical, referential and social gender (Hellinger and Motschenbacher 2015, 6), and the fact that Russian is a language with a grammatical gender means that all nouns fall into a gender category-masculine, feminine or neuter. Masculine and feminine gender nouns are unmistakably recognized by Russian speakers as referring to the social categories of femininity and masculinity. Although most terms denoting occupations have both masculine and feminine forms, quite a few nouns do not have a feminine counterpart, which aggravates the already existing issue of higher frequency of masculine-male expressions in Russian public communication (Hellinger and Bussmann 2001, 261). In the 2000s, to overcome the "androcentric perspective" of the Russian language (Hellinger and Bussmann 2001, 270), feminist activists started introducing into their online communication new feminine counterparts of masculine nouns formed with the suffix " $k$ " and feminine gender ending "a," for example, "doktor-doktorka." These words were used in cases when the Russian lexicon did not have a feminitive to refer to a female 
professional: for example, "avtorka" (authoress), "redaktorka" (editoress), "direktorka" (directoress). Throughout the 2000s and early 2010s, discussions about effectiveness and urgency of feminitives were mainly conducted within the Russian feminist movement, primarily online but also in offline spaces. As of the late 2010s, these debates have entered mainstream public discourses, both in digital and offline spaces, and have polarized Russian society into supporters of such linguistic visibility for women and opponents, who are worried about the purity of the Russian language affected by feminist linguistic innovations.

\subsection{Women's and Queer Online Activism}

When it comes to challenging and transgressing patriarchal discourses on women's gendered behavior and social roles, digital media offer Russian women invaluable opportunities for activism. In the same way that digital media have impacted politics in general, transforming top-down political hierarchies into participatory networks (Dartnell 2006), social movements and the notion of social activism have also evolved in the Internet era. Protest voices (Couldry 2010) have been amplified by social media campaigns (Jenkins et al. 2016; Kaun 2017) and citizen journalists generating amateur media-content on social media have come to be considered a reliable and trustworthy source of information (Bewabi and Bossio 2014). Since their appearance in the global media landscape, social networking sites, or social media, have evolved from focusing on "bonding social capital," that is, social bonds within a family or a small local or ethnic community, to "bridging social capital" by providing links across ethnic groups or between various communities and "linking social capital" by offering a new means of communication between political elites and the general public and between different social classes (Flew 2014, 66-67). Social networks have become an integral part and a valuable tool of participatory media cultures across the globe (Flew 2014, 77-78). Like other internet resources, social networking sites can be viewed as dynamic horizontal communication spaces (Youngs 2013, 176), which, due to the shared internet tools' characteristics of multiplicity and interactivity, are often perceived as resources with "radical liberatory potential" (Curran et al. 2012, 151).

Despite Runet being prone to state surveillance and political monitoring (Uldam 2018), its users nevertheless enjoy a high level of participation and autonomy (Curran et al. 2012, 164), which is especially high on social media platforms. Taking political and social protest to social networking sites provides activists with wider opportunities for contacting like-minded people and promoting individually framed agendas. Social networking sites thus afford a means of coordinating and boosting collective action of various social movements: "collective actions are also becoming more inclusive, that is, they encourage participation of those who would not want to commit to the interpretations of a formal group and who would traditionally not be the target of organizational outreach efforts" (Schumann 2015, 55). Although the digital 
divide still has a gendered dimension, in that women have suffered from inequalities in terms of access to the internet and other ICT (Ross and Byerly 2004, 187), the Internet has also enabled a considerable empowerment for women through cyberpolitics and cyberfeminism (Ross and Byerly 2004, 197-198). This is especially so for women involved in grassroots and community groups, whose activism increasingly takes place on the internet (Ross and Byerly 2004, 200). Internet-based activism has become vital for feminist activists and activist groups promoting the rights of lesbian, bisexual and transgender (LBT) women (Brown et al. 2017; Serano 2013).

Online feminist activism in Russia is developing fast and evolving consistently, comprising a variety of platforms and employing various strategies, among them - those of emotional capital and of "do it yourself" (DIY) brand identity (Turner 2010). Social media platforms offer Russian feminists such important tools as opportunities for transgressing patriarchal discourses, creating safe digital spaces in the form of emotional communities, and managing their own online identity as personal celebrity or influencer brands. On the other hand, activism performed online entails potential threats in the form of cyberbullying. For example, the case of the 2019 "Lushgate" campaign in support of prominent Russian feminist and lesbian activist Bella Rapoport, introduced into media discourses a debate on what kinds of online emotional expressions are acceptable for a woman. In March 2019, in an Instagram story Bella expressed her disappointment in the Lush handmade cosmetics brand which claims to be pro-feminist but failed to extend its support to her, that is, rejected her offer to collaborate. This made Bella a subject of cyberbullying across various social media platforms: she received hate mail via direct messaging on Instagram; Twitter users (both personal and corporate accounts) started a flashmob making a ridicule of Bella's correspondence with Lush; the activist received hateful and threatening comments and messages on her personal Facebook page. ${ }^{14}$ The cyberbullying was further promoted by multiple online media and mainstream media. The emotions shared in the Instagram story were interpreted as a transgression of socially acceptable feminine emotional boundaries by an overdemanding and self-absorbed feminist: a "good" woman does not use her emotions to demand benefits for herself but uses them to provide benefits for others. The example of "Lushgate" is only one of the numerous cases where Russian feminist activists faced a backlash of complex societal responses to their transgressive emotional expression and gendered behavior while performing their activism online.

Hashtag campaign mobilizations work to make women's and feminist voices heard in situations of aggressive misogyny. Similar to emotional management, hashtags provide a form of active and quick mobilization as an immediate response to abusive actions. A hashtag, created as a means of structuring content in social networks, is increasingly used to attract attention to social and political issues and events. After its emergence, hashtag campaigns were considered mainly in the context of protests against government actions and decisions. Nowadays more and more attention is being attracted to hashtag 
campaigns, which are against existing social practices, behavior and norms. In these cases, the protest is addressed not so much to the state as it is to power in a broader sense. Such campaigns often take the form of discursive activism that was described by Shaw (2012) as "speech or texts that seek to challenge opposing discourses." Here the issue of participants' choice of discursive strategies might be raised (Arbatskaya 2019).

Russian feminists and activists have started using hashtags increasingly after a very powerful "flashmob" \#yaNeBoyusSkazati/t (in Ukrainian and Russian, respectively; "I am not afraid to tell”) started by a Ukrainian activist, Anastasiya Melnichenko, in Summer 2016. In response to a Facebook post blaming women for becoming victims of rape, Melnichenko shared her own story of sexual assault with the hashtag. The post went viral across Ukrainian- and Russian-language social media: hundreds of women shared their own stories of sexual assault and sexual harassment at work. In the first two months alone, there were 12,282 original posts and over 16 million views (Aripova and Johnson 2018). Following the success of \#yaNeBoyusSkazati/t, other hashtag campaigns followed: \#etoNePovodUbit' (\#ItIsNotaReasonToKill) in 2018 and \#yaBoyusMuzhchin (\#IAmAfraidOfMen) in 2019. All of them represent an example of participants' attempt to challenge patriarchy by sharing stories of abuse that women are not supposed to talk about. By articulating trauma and translating it into narratives, these campaigns also provided therapeutic effect as well as solidarity and space for sharing.

At same time, there is plenty of online resistance to feminist and women's activism. Conservative social movement organizations (SMO) utilize online spaces for their own brand of activism to claim legitimacy by supporting traditional values that include stereotypical gender roles, the heteronormative family, protection of the family, and attacking anyone who says different. They efficiently use tools that are similar to those used by feminist activists: exclusive online spaces and hashtags as a response to what they see as a threat to "authentic Russia." The SMOs such as Sorok Sorokov (www.soroksorokov.ru) and AllRussian Parental Resistance (RVS, www.rvs.su) have very visible online presence by conducting aggressive mobilization campaigns and organizing fake media events. Their media is de-personified by using the pronoun "we"; they rarely mention any representatives by names, instead hiding behind webpages and hashtags. Their most recent campaign is resistance to passing prevention of domestic violence law in the Russian Federal Assembly (Russian parliament). Not only they started an abusive and aggressive media campaign against the law and its authors (all women), they also mobilized online using hashtag \#zaSemyu (\#ProFamily) to encourage their supporters to participate in an online discussion of the draft at the Council of Federation (upper house of the parliament) webpage. 


\subsection{CONCLUSION}

Mirroring the complex discourse on gender roles and gender equality in contemporary Russian society, digital spaces have evolved into a battleground for new gender politics and identities. Early cyberfeminists and activists considered those spaces safe, safer than actual public spaces for protest (see, e.g., Rollestone Collective 2014), which has resulted in the existence of a wide and diverse variety of online communities, activist public accounts, and personal blogs with a solid potential to influence and shape offline debates on the feminism, nonheteronormative identities, men's and women's rights. However, the example of Runet together with other "nets" suggests that people take their politics and their materiality to virtual spaces that, in turn, are becoming even more dangerous due to illusion of safety. Cases of cyberstalking, cyberbullying, and simple online campaigns calling to "deal" with feminist and LGBTQ+ activists make us revisit the concept of cyberspace. In Russia, the situation is further aggravated by selective but tight state-imposed control and censorship over internet as well as state's official patriarchal discourse.

Yet, the development of gendered online practices, tools and strategies point to an emergence of mosaic virtual reality in which multiple identities debate and negotiate but remain fluid in its discursivity. Russian feminist and antifeminist and anti-gender conflict online mirrors a global backlash against feminism in digital media. Online spaces and digital platforms reproduce materiality of "real-life" conflict with serious political consequences. In Russia, gender politics online and offline indicates the debates and negotiations important for constructing identities in situations when freedom of expression can be limited. Russians use online and digital platforms as a strategy to communicate their difference to the State and to their fellow Russians.

\section{Notes}

1. Source: https://memepedia.ru/tyan-ne-nuzhny-tnn/, accessed December $4,2019$.

2. Source: https://vk.com/mensrights, accessed March 27, 2020.

3. See, for example, "Not as ironic as I imagined: the incels spokesman on why he is renouncing them," by the Guardian, published on July 19, 2018, https:// www.theguardian.com/world/2018/jun/19/incels-why-jack-peterson-leftelliot-rodger, accessed December 13, 2019.

4. See, for example, “Tân ne nužny: agressivnye devstvenniki stanovâtsâ novymi terroristami [We don't need chans: aggressive virgins become new terrorists]," by Russian TV channel NTV, published on November 16, 2019, https://www.ntv. ru/novosti/2255780/, accessed December 13, 2019.

5. See "Women must provide sex for everyone: The most famous incel of Russia to be trialed for the ideas of vaginocapitalism," by the Russian newspaper Komsomol'skấ pravda, published on December 12, 2019, accessed December 13, 2019. https://www.kp.ru/daily/27062.5/4130982/.

6. Source: https://www.mlg.ru/ratings/, accessed November 27, 2019. 
7. Source: https://www.tiktok.com/@alexmymymy, accessed March 27, 2020.

8. Source: https://www.youtube.com/channel/UC0UK9eo_m6v4DDGXQKQf5Ww, accessed December 4, 2019.

9. The episode is available at https://www.youtube.com/watch?v=ksdptbnbu8c, accessed December 13, 2019.

10. Source: https://vk.com/zaiki_luzhaiki, accessed March 27, 2020.

11. Source: https://vk.com/prelesti_braka, accessed March 27, 2020.

12. "9 inclusivity activists from Russia you need to follow on Instagram," by the Calvert Journal, published on March 9, 2019, https://www.calvertjournal. $\mathrm{com} /$ articles/show/11058/9-inclusivity-activists-from-russia-you-need-tofollow-on-instagram, accessed December 13, 2019.

13. Source: https://nasiliu.net/nuzhna-pomoshh/mobilnoe-prilozhenie/.

14. See, for example, "Lush vs. activist: a serious debate about feminism born out of a Twitter craze," by the RT's multimedia project Russia Beyond, published on March 26, 2019, https://www.rbth.com/lifestyle/330157-lush-vs-activistserious-debate-feminism, accessed December 13, 2019.

\section{REFERENCES}

Arbatskaya, Elena. 2019. Discursive Activism in the Russian Feminist Hashtag Campaign: The \# ItIsNotAReasonToKill Case. Russian Journal of Communication 11 (3): 253-273.

Aripova, Feruza, and Janet Elise Johnson. 2018. The Ukrainian-Russian Virtual Flashmob Against Sexual Assault. The Journal of Social Policy Studies 16: 487-500.

Arvidsson, Viktor, and Anna Foka. 2015. Digital Gender: Perspective, Phenomena, Practice. First Monday 20. https://firstmonday.org/ojs/index.php/fm/article/ view/5930/4430; https://doi.org/10.5210/fm.v20i4.5930.

Bewabi, Saba, and Diana Bossio, eds. 2014. Social Media and the Politics of Reportage. The "Arab Spring". London: Palgrave Macmillan.

Bourdieu, Pierre. 2001. Masculine Domination. Stanford: Stanford University Press.

Bouvier, Gwen, ed. 2018. Discourse and Social Media. London and New York: Routledge.

Brown, Melissa, Rashwan Ray, Ed Summers, and Neil Fraistat. 2017. \#SayHerName: A Case Study of Intersectional Social Media Activism. Ethnic and Racial Studies 40 (11): 1831-1846. https://doi.org/10.1080/01419870.2017.1334934.

Castells, Manuel. 2010. The Power of Identity. 2nd ed. Malden, MA: Wiley-Blackwell.

Chan, Lik Sam. 2018. Liberating or Disciplining? A Technofeminist Analysis of the Use of Dating Apps Among Women in Urban China. In Communication, Culture and Critique 11 (2): 298-314. https://doi.org/10.1093/ccc/tcy004.

Collective, Roestone. 2014. Safe Space: Towards a Reconceptualization. Antipode 46 (5): 1346-1365.

Couldry, Nick. 2010. Why Voice Matters. Culture and Politics After Neoliberalism. Los Angeles: SAGE.

Cucciola, Mario, ed. 2017. State and Political Discourse in Russia. Rome: ResetDialogues on Civilizations.

Curran, James, Natalie Fenton, and Des Freedman. 2012. Misunderstanding the Internet. London and New York: Routledge. 
Dartnell, Michael Y. 2006. Insurgency Online. Web Activism and Global Conflict. Toronto and Buffalo: University of Toronto Press.

Doshi, Marissa J. 2018. Barbies, Goddesses, and Entrepreneurs: Discourses of Gendered Digital Embodiment in Women's Health Apps. Women's Studies in Communication 41 (2): 183-203.

Flew, Terry, ed. 2014. New Media. South Melbourne and Victoria: Oxford University Press.

Gnedash, A.A. 2012. Ženskie soobŝestva v onlajn-prostranstve: 'Režimy vidimosti’ v publičnoj politike RF. Ǔžno-rossijskij žurnal social'nyh nauk, no. 1: 97-103. https:// cyberleninka.ru/article/n/zhenskie-soobschestva-v-online-prostranstve-rezhimyvidimosti-v-publichnoy-politike-rf.

Goscilo, Helen, and Yana Hashamova, eds. 2010. Cinepaternity. Fathers and Sons in Soviet and Post-Soviet Film. Bloomington and Indianapolis: Indiana University Press.

Goscilo, Helen, and Vlad Strukov, eds. 2011. Celebrity and Glamour in Contemporary Russia. Shocking chic. London and New York: Routledge.

Green, Eileen, and Alison Adam, eds. 2001. Virtual Gender: Technology, Consumption, and Identity. London: Routledge.

Guzaerova, Regina, Drahomira Sabolová, and Vera A. Kosova. 2018. Russian Feminine Nouns with Suffix -k(a) in the Modern Mediaspace. Revista San Gergorio, no. 25: 36-43. https://dialnet.unirioja.es/servlet/articulo?codigo $=6841019$.

Hellinger, Marlis, and Hadmund Bussmann, eds. 2001. Gender Across Language: The Linguistic Representation of Women and Men, Volume 1. Amsterdam and Philadelphia: John Benjamins Publishing Company.

Hellinger, Marlis, and Heiko Motschenbacher, eds. 2015. Gender Across Languages 4. Amsterdam and Philadelphia: John Benjamins Publishing Company.

Hodder, Ian. 2012. Entangled: An Archaeology of the Relationships Between Humans and Things. Malden, MA: Wiley-Blackwell.

Huppatz, Kate. 2012. Gender Capital at Work. Intersections of Femininity, Masculinity, Class and Occupation. Basingstoke: Palgrave Macmillan.

Jenkins, Henry, Sangita Shresthova, Liana Gamber-Thompson, Neta Kligler-Vilenchik, and Arely M. Zimmerman. 2016. By Any Media Necessary. The New Youth Activism. New York: New York University Press.

Kaganovsky, Liliya. 2008. How the Soviet Man was Unmade. Cultural Fantasy and Male Subjectivity Under Stalin. Pittsburgh: University of Pittsburgh Press.

Kaun, Anne. 2017. 'Our Time to Act Has Come': Desynchronization, Social Media Time and Protest Movements. Media, Culture \& Society 39 (4): 469-486. https:// doi.org/10.1177/0163443716646178.

Kay, Rebecca. 2006. Men in Contemporary Russia: The Fallen Heroes of Post-Soviet Change? London: Ashgate.

Kon, Igor. 1995. The Sexual Revolution in Russia. From the Age of the Czars to Today. New York: The Free Press.

Kudaibergenova, Diana T. 2019. The Body Global and the Body Traditional: A Digital Ethnography of Instagram and Nationalism in Kazakhstan and Russia. Central Asian Survey 38 (3): 363-380. https://doi.org/10.1080/0263493 7.2019.1650718.

Lokot, Tetyana. 2019. Affective Resistance Against Online Misogyny and Homophobia on the RuNet. In Gender Hate Online, ed. Debbie Ging and Eugenia Siapera, 213-232. Cham: Palgrave Macmillan. 
Mohanty, J.R., and Swati Samantaray. 2017. Cyber Feminism: Unleashing Women Power Through Technology. Rupkatha Journal of Interdisciplinary Studies in Humanities 9 (2): 328-336.

Pilkington, Hilary, ed. 1996. Gender and Identity in Contemporary Russia. London, andNew York: Routledge.

Plant, Sadie. 2000. On the Matrix: Cyberfeminist Simulations. In The Cybercultures Reader, ed. David Bell and Barbara M. Kennedy, 325-336. New York: Routledge.

Pottinger, Laura. 2017. Planting the Seeds of a Quiet Activism. Area 49 (2): 215-222.

Ross, Karen, and Carolyn M. Byerly, eds. 2004. Women and Media. International Perspectives. Oxford: Blackwell Publishing.

Salmenniemi, Suvi. 2008. Democratization and Gender in Contemporary Russia. London and New York: Routledge.

Schumann, Sandy. 2015. How the Internet Shapes Collective Actions. Basingstoke: Palgrave Macmillan.

Serano, Julia. 2013. Excluded. Making Feminism and Queer Movements More Inclusive. Berkeley, CA: Seal Press.

Shaw, Francis, 2012. The Politics of Blogs: Theories of Discursive Activism Online. Media International Australia 142: 41-49.

Solovyeva, Olga, and Olga Logunova. 2018. Self-Presentation Strategies Among Tinder Users: Gender Differences in Russia. In International Conference on Digital Transformation and Global Society, 474-482. Cham: Springer.

Sremac, Srdjan, and Ruard Ganzevoort, eds. 2015. Religious and Sexual Nationalisms in Central and Eastern Europe. Gods, Gays and Governments. Leiden and Boston: Brill.

Stella, Francesca. 2015. Lesbian Lives in Soviet and Post-Soviet Russia: Post/Socialism and Gendered Sexualities. Basingstoke and New York: Palgrave Macmillan.

Stella, Francesca, and Nadya Nartova. 2015. Sexuality, Nationalism and Biopolitics in Putin's Russia. In Sexuality, Citizenship and Belonging: Trans/National and Intersectional Perspectives, ed. Francesca Stella, Yvette Taylor, Tracey Reynolds, and Antoine Rogers. London: Routledge.

Turner, Graeme. 2010. Ordinary People and the Media. The Demotic Turn. Los Angeles: SAGE.

Uldam, Julie. 2018. Social Media Visibility: Challenges to Activism. Media, Culture of Society 40 (1): 41-58. https://doi.org/10.1177/0163443717704997.

Vivienne, S., A. McCosker, and A. Johns. 2016. Digital Citizenship as Fluid Interface: Between Control, Contest and Culture. In Negotiating Digital Citizenship: Control, Contest and Culture, ed. A. McCosker, S. Vivienne, and A. Johns, 1-17. Rowman and Littlefield International.

Youngs, Gillian. ed. 2013. Digital world: connectivity, creativity and rights. LondonNew York: Routledge.

Yusupova, Marina. 2018. Between Militarism and Antimilitarism: 'Masculine' Choice in Post-Soviet Russia. In Gender and Choice After Socialism, ed. L. Lynne Attwood, Elisabeth Schimpfössl, and Marina Yusupova. Cham: Palgrave Macmillan.

Zdravomyslova, Elena, and Anna Tyomkina, eds. 2007. Rossijskij gendernyj porâdok: sociologĩceskij podhod [Russian Gender Order: A Sociological Approach]. Saint Petersburg: European University Press. 
Open Access This chapter is licensed under the terms of the Creative Commons Attribution 4.0 International License (http://creativecommons.org/licenses/ by $/ 4.0 /)$, which permits use, sharing, adaptation, distribution and reproduction in any medium or format, as long as you give appropriate credit to the original author(s) and the source, provide a link to the Creative Commons licence and indicate if changes were made.

The images or other third party material in this chapter are included in the chapter's Creative Commons licence, unless indicated otherwise in a credit line to the material. If material is not included in the chapter's Creative Commons licence and your intended use is not permitted by statutory regulation or exceeds the permitted use, you will need to obtain permission directly from the copyright holder. 